\title{
【はじめに】
}

実験的内耳 Barotrauma モデルにおける螖牛の形態学的研究については、光顕、位相差 顕微鏡、電子顕微鏡（SEM）により、当教室をはじめ報告されている。

今回、我々は、周波数別の聴力と螖牛の病態を電気生理学的に検討する目的で実験を行 った。実験は、高気圧負荷をかけたモルモットを使用し、周波数別に蝸牛マイクロホン電 位（CM），蝸牛神経複合活動電位（CAP）を測定し、直ちに断頭し SEM 標本作製を行い、 比較検討した。

\section{【方 法】}

白色ハートレーモルモット112匹（体重150〜200gで Preyer 反射正常）の右耳を使用 し、高気圧負荷直後にPreyer 反射の消失、減弱、または眼振の出現したモルモットを内

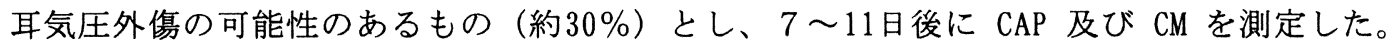
高気圧負荷の条件は、純酸素を用いて、大気圧から 2 気圧に 30 秒で変化させ、10分間維持 し、30秒で大気圧にもどした。負荷後 $7 〜 11$ 日後に測定したのは、併発の考えられる中耳 Barotra uma の急性期傷害の影響（伝音難聴）をできるだけ除外するためである。また、 測定時に蝸牛骨胞内を観察し、中耳炎を合併したものや鼓膜穿孔、耳小骨連鎖異常のある 例は対象とせず、血塊は出来る限り排除した。したがって、最終的な検討対象を17耳とし た。CM, CAP の測定は銀ボール電極を基底回転鼓室階の骨壁上に設置し、刺激音は $1 \mathrm{k}, 2 \mathrm{k}$, $4 \mathrm{k}, 8 \mathrm{kHz}$ のトーンバーストにて行った.コントロール群としては、高気圧負荷をかけない 同種モルモット 5 匹を使用した. 各周波数毎に、CAP はN 1 の振幅, 見かけの域值, 潜時 を、CM は振幅, 見かけの域値を検討した。SEM は上記測定後、直ちに断頭し標本作製を 行った。

\section{【結 果】}

図 1 に、対象 17 例における周波数別の CAP 域值と CM 域值の重ね合わせオージオグラ ムを示す。今回示す CAP と CM の域值は、すべてコントロール 5 例の各周波数別の平均 值を $0 \mathrm{~dB}$ とて、各例の見かけの域值を換算したものである。このように、CAP, CM とも に、高度に障害されたものと軽い障害のものと比較的明瞭に分かれた。また、CMにおい ては、高音部が比較的維持されていた。

17 例の特徵を一覧にしたものを図 2 に示す。

図 1 のオージオグラム上より、高度障害群（A群）と軽度障害群（B 群）に便宜的に分け た。B群の中には、コントロールと大きな差のない域值を示したものも多かった。ただし、 中耳気圧外傷の発生によりPreyer 反射が低下し、測定までに回復したものがあることは 否定できない。

このように多くの例では、CAP とCM の域值はほぼ一致していたが、いくつかの例に おいて CAP と CM の解離が見られた。特に、30dB 以上の解離を認めたものが4例存在し、 いずれもその解離は高音域で見られた（図 3 ）。SEMの所見と比較すると、高度の CAP 
低下を認めたNo.4では、第 $2 \sim 3$ 回転において外有毛細胞の聴毛の多くは消失し残存し た聴毛は癒合しており、内有毛細胞の聴毛の多くはなぎ倒されていた。一方、高音部の CAP 低下を認めながら、CM は保たれているNo.6では、基底回転においてほぼ正常の SEM 所見を示していた。

\section{【結 論】}

CM, CAP の周波数別のみかけの域値を指標とした場合、得られた聴力型に一定の傾向は 認めなかった。また、一部の例において CM と CAP に解離傾向が認められた。今回の結 果より、SEM による形態学的観察結果と CAP、CM を指標とした周波数別の聴力には、ある 程度の関連を認めていたと思われるが、1部に CAP とCM の解離が認められたことは興 味深い所である。また、高気圧負荷後のモルモットの 1 週間から11日後の CAP と CM の 測定で、軽度障害群と高度障害群に分かれたことは、改善傾向のある群と不可逆性の群に 分かれたとも考えられる。軽度障害群のうち、SEM の所見を確認できた例のコルチ器表面 の形態は、負荷後 1 週間から 11 日後においては、ほぼ正常であった。また、軽度障害例の うちで、CAP と CM の解離を示した 1 例も、SEM では明らかな異常を認めなかった。つま リ、SEM の所見上形態的にほぼ正常であっても、完全な聴力回復が得られていない可能性 があるものと思われる。 图 1
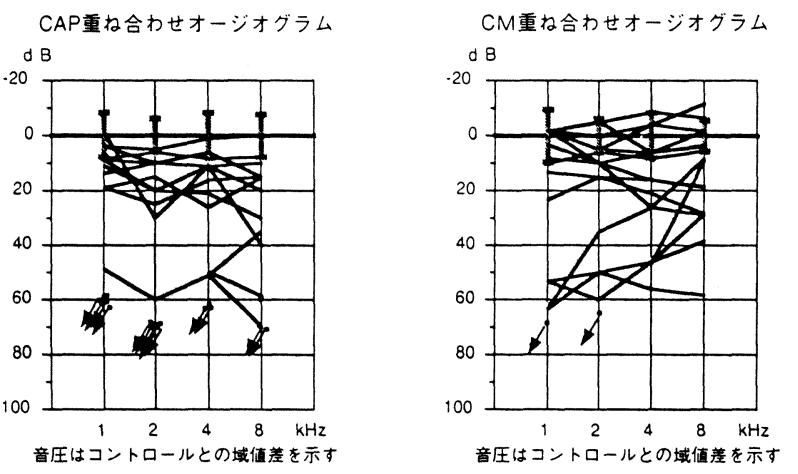

図3

CAPとCMの解離4例

No. 2

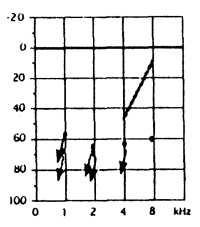

$\mathrm{N} \circ .3$

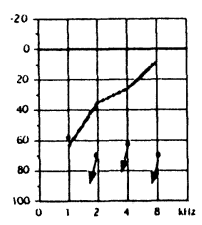

No. 5

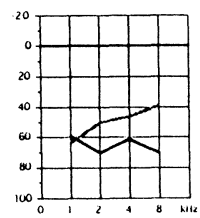

$\mathrm{N} \circ \mathrm{T}$

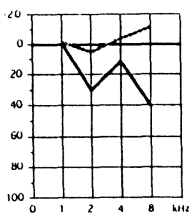

